"IFRS convergence: opportunities and challenges in India"

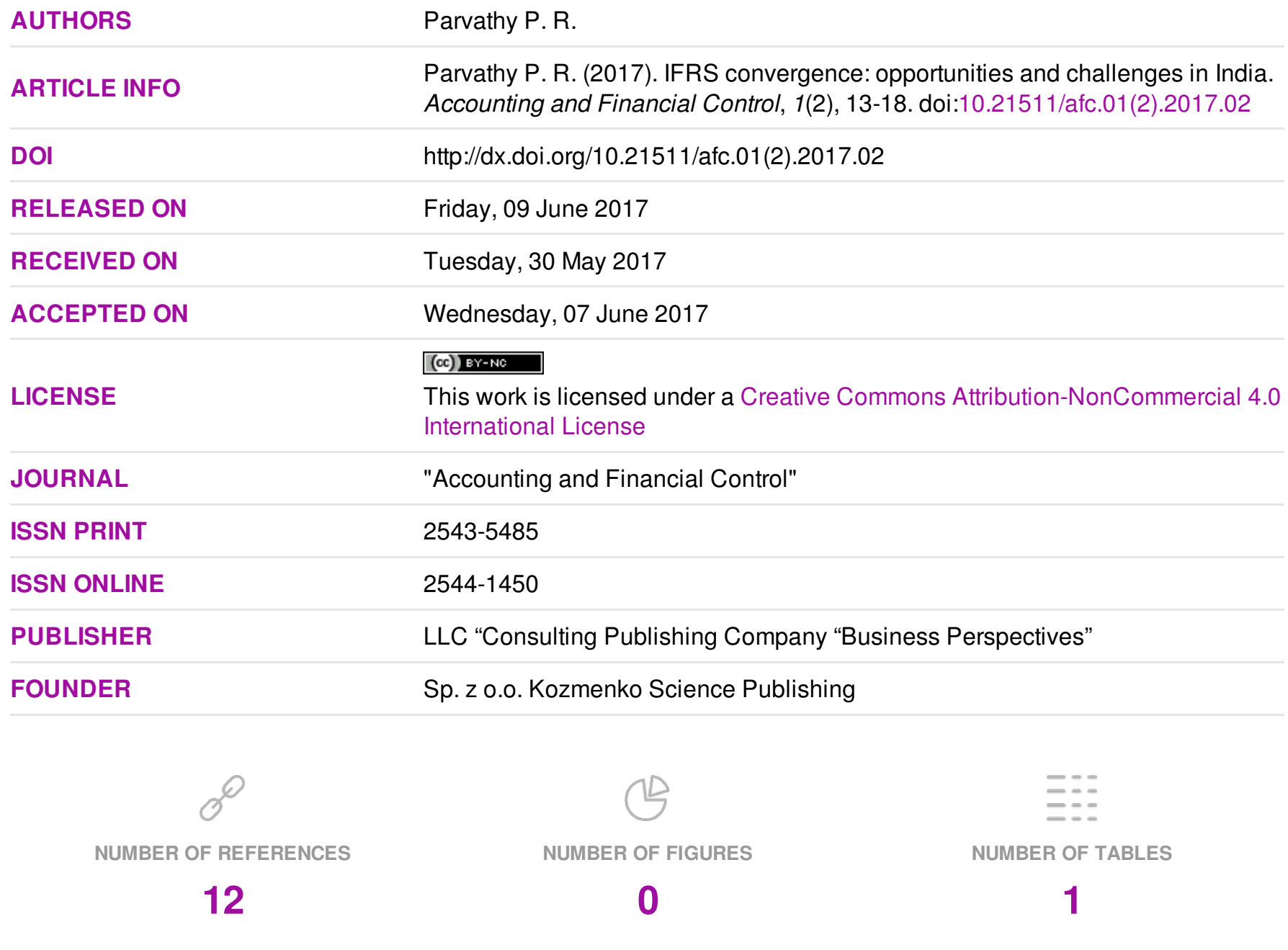

(C) The author(s) 2022. This publication is an open access article. 


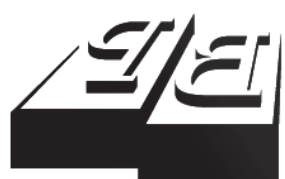

BUSINESS PERSPECTIVES

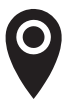

LLC "CPC "Business Perspectives" Hryhorii Skovoroda lane, 10, Sumy, 40022, Ukraine

www.businessperspectives.org

Received on: $16^{\text {th }}$ of May, 2017 Accepted on: $7^{\text {th }}$ of June, 2017

(C) Parvathy P. R., 2017

Parvathy P. R., Post Graduate student (Master of Commerce), Farook College (Autonomous), Calicut, Kerala, India.

\section{IFRS CONVERGENCE: OPPORTUNITIES AND CHALLENGES IN INDIA}

\begin{abstract}
Past decade has witnessed several changes in the process of conduct of business activities across the world especially due to the wave of globalization. It has also made drastic changes in the process of financial reporting, in particular the continuing adoption of IFRS (International Financial Reporting Standards) worldwide. IFRS are high quality, understandable, enforceable and globally acceptable accounting standards issued by IASB (International Accounting Standard Board). Thus these are a set of international accounting standards stating how a particular type of transaction and other events should be reported in the financial statements. Thus IFRS are designed as a common global language for business affairs so that company accounts are understandable and comparable across international boundaries. IFRS is becoming the global language of business with over $40 \%$ of the world adopting this as their standard for reporting. India also decided to converge to IFRS from 1st April 2016 in a phased manner, which in turn improves the financial statement comparability and transparency that helps to attract greater cross border investments. This paper focuses on the convergence of IFRS with Indian Accounting Standards, its utility, issues and challenges faced by the stakeholders. It also throws light to the ways through which problems can be addressed.
\end{abstract}

\section{Keywords}

\section{JEL Classification} reporting, stakeholders, financial statements

\section{G30, M41}

\section{INTRODUCTION}

Financial reporting is the process of disclosure of financial information to the management and the public about a company's performance over a specific period of time. There are well defined principles for accounting known as Accounting Standards. With the advent of globalization, the financial reporting of business activities underwent a great deal of change which includes the adoption of IFRS (International Financial Reporting Standards).

IFRS are high quality, understandable, enforceable and globally acceptable accounting standards issued by IASB (International Accounting Standard Board). Thus these is a set of international accounting standards stating how a particular type of transaction and other events should be reported in the financial statements. The ultimate goal of issuing these standards is to achieve a single set of high quality, common accounting standards that is practiced all around the world so as to facilitate transparency of financial information. Before IFRS we had IAS (International Accounting Standards) issued by IASC (International Accounting Standards Committee). In India, Accounting Standard 
Board (ASB) of India constituted under the ICAI (Institute of Chartered Accountants of India) sets and publishes the standards in tune with IAS. Since India has its own accounting standards that are different on many counts, following a set of common standards that are altogether different in practice will require some compromise between prevailing standard norms and new provisions.

Thus at present, as we cannot adapt to IFRS due to our legal constraints, we have prepared our own standards for application for a limited period known as IndAS (Indian Accounting Standards). Actually these are IFRS converged Indian Accounting Standards. These standards will be in practice for 3 years from now, by that period, we have to change our corporate legislation to suit the international level.

\section{LITERATURE REVIEW}

Preethi, Deepti \& Rawat (2015). A study on "Challenges and Prospects of IFRS in Indian Accounting Systems" was done by Dr. Preethi Shrivastava, Dr. Deepti Maheswari and D.S. Rawat. The main focus of the study was whether by following the converged IFRS the primary objective of uniformity and comparability of the financial statements prepared in India with rest of the countries of globe will be achieved. They came to a conclusion that the benefits of global accounting standards irrespective of its various challenges will change the contents of the corporate financial statements leading to greater transparency and comparability.

Govindarajan (2014). A study on "Introduction to IFRS and Convergence" was done by N. Govindarajan, in which he mentioned about what is IFRS, its needs, Convergence and challenges faced by the stakeholders. He concluded that the convergence of IFRS with Indian Standards will, of course, benefit us.

Kirit \& Meenakshi (2015). A study on the topic "IFRS: Challenges Ahead" was done by Prof Kirit Magana and Dr. Meenakshi Somani. Here the main attention was on the benefits of IFRS to the Indian Corporate and Professionals, its key issues and challenges. The findings of the study were that a single set of high quality standards would be in public interest and would provide a uniform language for financial reporting which, in turn, will have a positive impact overall.

ASSOCHAM (2014). A study on the topic "IFRS in India" was done by ASSOCHAM, Hyderabad. It analyzed the Global Convergence of Accounting Standards with Indian Standards. It also focused on the use IFRS to various countries.
Shanthanu (2015). Shantanu Kumar Das did study entitled "Indian Accounting Standards and IFRS" in 2014. The main goal of the study was the comparison of India Accounting Standards with IFRS, in which he concluded that the global accounting standards would remove a frictional element to capital flows and lead to wider and deeper investment in markets with the adoption of IFRS.

\section{OBJECTIVES, RESEARCH PROBLEMS AND METHODOLOGY}

The objectives of the paper are following:

- to explore the present landscape of IFRS convergence in India;

- to examine the application of international financial reporting standards in the Indian context;

- to examine the India`s utility or opportunity in IFRS adopting;

- to analyze the problems faced by stakeholders due to the convergence of IFRS with Indian Accounting Standards.

IFRS is one of the recent developments in the field of standard setting. Here, an attempt is made to bring in parity in the reporting of financial statements before the users by trying to formulate a single set of standards to be followed by the world. Since many countries including India have their own National accounting standards that are different on many counts, especially on socio-economic, cultural and legal norms, following a set 
of common standards that are altogether different in practice will require some compromise between prevailing standard norms and new provisions. The paper mainly attempts to focus on the convergence of IFRS with Indian standards, opportunities and problems being faced in the convergence of IFRS with Indian Accounting Standards.

The study deals with the convergence of IFRS in financial reporting in India and impact among stakeholders. It blends descriptive and exploratory research work. The data is purely secondary and is collected through journals, articles, websites, dailies as well as published books.

The study is organized into different sections such as:

- IFRS and its Need;

- Convergence of IFRS and Indian Accounting Standards;

- Opportunities;

- Challenges.

\section{KEY RESEARCH FINDINGS}

\subsection{IFRS and its need}

IFRS are high quality, understandable, enforceable and globally acceptable accounting standards issued by IASB (International Accounting Standard Board). Thus these is a set of international accounting standards stating how a particular type of transaction and other events should be reported in the financial statements. The ultimate goal of issuing these standards is to achieve a single set of high quality, common accounting standards that is practiced all around the world so as to facilitate transparency of financial information. This is a framework that establishes recognition, measurement, presentation and disclosure requirements relating to transactions and events that are reflected in the financial statements. It was developed in the year 2001 by IASB.

The need of IFRS:

- to make a common platform for better understanding of accounting;
- to create comparable, reliable and transparent financial statements;

- to synchronize the accounting standards across the globe;

- to increase and improve foreign investments;

- to increase the industrial growth;

- to remove information flow barriers.

IFRS hierarchy:

1. International Accounting Standards Committee Foundation. This is the body that oversees the international accounting standards.

2. International Accounting Standards Board (ISAB). This is the body that sets international financial reporting standards (IFRS) and approves interpretation.

3. International Financial Reporting Interpretations Committee (IFRIC). It is responsible for interpretation of standards and issue guidance on issues that have not yet been addressed by standards.

4. The Standards Advisory Council (SAC). This is a forum to provide broad strategic advice on IASB's agenda priorities and insights into cost and benefits of project.

IFRS comprises the following statements:

- International Accounting Standards (IAS);

- International Financial Reporting Standards (IFRS);

- Standard Interpretations (SIC);

- International Financial Reporting Interpretations (IFRIC).

\subsection{IFRS Convergence in India}

IFRS convergence, in recent years, has gained momentum all over the world. As capital markets become increasingly global in nature, more and more investors see the need for a common set of accounting standards. Approximately 100 countries have adopted and many have converged IFRS with their own standards (Table 1). 
Table 1. IFRS convergence in some countries

\begin{tabular}{l|c}
\hline \multicolumn{1}{c|}{ Country } & Year of implementation \\
\hline European countries & 2005 \\
\hline Canada & 2011 \\
USA & 2016 \\
Japan & 2016 \\
\hline Nepal & 2011 \\
Brazil & 2010 \\
\hline India & 2016 \\
\hline
\end{tabular}

In India, Accounting standards are formulated by council of Institute of Chartered Accountants of India (ICAI). In July 2007, ICAI set a target of adopting IFRS for all listed, public interest and large sized entities from April 2011. In 2007 India decided to converge to IFRS. The accounting standards that are converged with IFRS are known as Indian AS. Thus in India Indian Accounting Standard Board and IASB continue to collaborate together to develop high quality, compatible accounting standards rather than adopting IFRS by itself. In India Ministry of Corporate affairs has announced the implementation of new standards effective from $1^{\text {st }}$ April 2016 in a phased manner. Existing standards will cease to apply after that dates. The Ministry of Corporate Affairs notified the implementation plan in a phased manner over a period of four years. i.e., from $1^{\text {st }}$ April 2016 to $1^{\text {st }}$ April 2019. This leads to the necessity of learning new standards at the earliest.

As per the notification of the Ministry the mandatory implementation dates are:

- For listed companies with net worth of Rs. 500 crores or more - from $1^{\text {st }}$ April 2016;

- For listed companies with net worth of Rs. 250 crores or more - from $1^{\text {st }}$ April 2017;

- For Banks and Insurance Companies from $1^{\text {st }}$ April 2019.

\subsection{Utility}

Economies across the globe have benefited by adopting IFRS for financial reporting purposes. Some of the benefits to Indian firms by convergence to IFRS are following:
1. Better access to global capital markets.

As a result of global expansion, or so-called globalization, along with the growth and expansion, of course, they need funds from cheaper sources. Convergence to IFRS helps Indian firms to procure capital from abroad.

2. Better cross border listing.

As Indian firms acquire funds for their major expansion plans from outside the boundaries of India, it is imperative for them to follow IFRS. Thus by following IFRS it becomes easier for the Indian Companies to list abroad.

3. Elimination of multiple reporting.

Large business entities will have their subsidiaries registered in India as well as outside. Firms in India prepare their accounting according to Indian Accounting Standards whereas those registered in foreign countries have to prepare accounting according to financial reporting standards of these countries. Convergence to IFRS ensures elimination of multiple financial reporting by these firms by following a single set of International Financial Reporting Standards.

4. Better quality of financial reporting.

IFRS are high quality, understandable, enforceable and globally acceptable accounting standards. Adoption to IFRS will result in better quality of financial reporting due to the consistent application of Accounting Principles and thus improves the reliability of the financial statements.

5. Easier global comparability.

As we know IFRS are becoming the global language for financial reporting. With the adoption of IFRS by the Indian firms the comparison becomes easier. Investors, bankers, lenders and other stakeholders also find it easier to compare the financial statements following the same reporting procedures. 
6. Improved cross border investments.

The adoption to IFRS improves the cross border investments by enhancing the comparability of financial statements prepared anywhere in the world.

\subsection{Challenges}

As in the case of two sides of a coin, along with utilities it also consists of challenges for the Indian firms. They are following:

1. Training. Lack of training and academic knowledge in IFRS is a challenge as far as Indian economy is concerned. Thus adequate training should be given to the stakeholders such as Chief Financial Officers (CFO), auditors, tax authorities. Then only it can be uniformly understood and consistently applied.

2. Awareness. The adequate knowledge about IFRS is still limited to few numbers of people in India. Most of the stakeholders like firms, banks, shareholders, exchanges etc. are not aware about the same. Such lack of awareness about these standards is one of the major challenges faced by Indians.

3. Amendments in Regulations. In order to adapt to IFRS, we need to amend our existing rules and regulations. As Indian accounting practices are governed by the Companies Act, 1956, Income Tax Act 1961, Reserve Bank of India Act, Insurance and Regulatory Authority of India Act, GAAP etc. which are different from IFRS, adequate changes must be made in order to follow IFRS. Thus legal constraints are major challenges would be faced.
4. Use of fair value measurement base. IFRS uses fair value base to measure majority of items in the financial statements. The use of fair value accounting can bring a lot of volatility and subjectivity in financial statements, e.g.: it would increase volatility in reported earnings and related performance measures such as EPS (Earnings per Share), PE (Price Earnings) Ratio etc. Thus fair value (reflecting the true worth of assets) results in gains or losses which are reflected in Profit and Loss accounts. Indian corporate entities which prepare financial statements on historical costs will need to have enough time for shifting into fair value accounting.

5. Financial reporting system. In India financial reporting is done according to standards issued by ICAI (Institute of Chartered Accountants of India). We need to amend the same to suit the requirements of IFRS. The information systems should be designed to capture new requirements related to fixed assets, segment disclosures, related party transactions etc.

6. SME concerns. Scarcity of resources and lack of expertise with SME (Small Manufacturing Sector) act as a barrier for the process of convergence to IFRS. As far as SME are concerned, cost would surpass its benefits as a result of convergence with the IFRS. Hence it acts as a challenge.

7. Change in IT Systems. Financial accounting and reporting systems must be able to produce robust and consistent data for reporting. The system must be capable of capturing new information required for disclosure such as fair values of financial instruments, related party transactions, segment information etc.

\section{CONCLUSION AND REMARKS}

Convergence of IFRS with the Indian Accounting Standards will, of course, ensure greater credibility in the international capital market. Adequate time is required to react to new changes and an intensive effort from all the stakeholders is imperative in order to achieve that goal. The process of convergence has been making a slow but steady progress in India and is expected to have a common set of high quality standards in adoption. There are several challenges that we come across while converging to IFRS, 
but the benefits from the same are worthier than that of its challenges. Regulators and law makers must implement efficient monitoring system of regulatory compliance of IFRS and should also ensure that proper changes are to be done in the existing laws for the same.

Based on research findings we suggest following:

1. Proper awareness should be given about IFRS and the need to converge the same to stakeholders.

2. More number of trainers should be engaged.

3. Adequate training should be given to develop a suitable system.

4. Necessary modification should be made in governing business and laws.

5. Government shall provide assistance as well as incentives to promote the same.

\section{REFERENCES}

1. ASSOCHAM. (2014). IFRS in India. Cost Accountants of India, 3-7.

2. Govindarajan, N. (2014). Introduction to IFRS and Convergence. Slide Share.

3. Gurpreet, K., \& Amit, K. (2014) IFRS in India: Problems and Challenges. Research gate.

4. Kirit, M., \& Meenakshi, S. (2015). IFRS: Challenges Ahead. ICAI, 24-27.

5. Meenu, S., \& Kavitha, N. V. (2011). A Study on IFRS in India. International Journal of Innovative Research and Development, 362-367.
6. Pawan, J. (2011). IFRS

Implementation in India:

Opportunities and Challanges.

Research Gate.

7. Preethi, S., Dr. Deepti, M., \& Rawat, D. S. (2015). Challenges and Prospects of IFRS in Indian Accounting Systems. International Journal of Core Engineering and Management, 142-149.

8. Richard, R. (2008). IFRS: Impact on Indian Corporates. The Economic Times.
9. Shanthanu, D. K. (2015). Indian Accounting Standards and IFRS. Slide Share.

10. Shobhan, S. (2013). IFRS Convergence and Applicability in India: Some Issues. Economic Times, 24-32.

11. Vinayagamoorthy, A. (2012). Oppertunities and challenges in adopting IFRS in India. International research journal of management sociology and humanities, 120-125.

12. Yash, B. (2012). Challenges in Convergence of India GAAP and IFRS. Slide Share. 